\title{
PELAKSANAAN PELAYANAN PENERIMAAN PESERTA DIDIK BARU (PPDB) PADA SEKOLAH DASAR AL-FATH CIRENDEU \\ TANGERANG SELATAN
}

\author{
Wiwin Wianti \\ Universitas Bina Sarana Informatika Jakarta \\ Wiwin.win@bsi.ac.id
}

\begin{abstract}
ABSTRAK: Salah satu upaya dalam meningkatkan mutu pelayanan di bidang pendidikan adalah dengan melakukan penyaringan peserta didik pada program Penerimaan Peserta Didik Baru dengan sistem semi online. Pelayanan Penerimaan Peserta Didik Baru semi online bertujuan agar mempermudah pendaftaran, informasi serta pengolahan akan hasil pendaftaran. Metode penelitian ini menggunakan penelitian deskriptif kualitatif dengan teknik pengumpulan data yang digunakan adalah teknik observasi, wawancara dan dokumentasi. Hasil penelitian pelaksanaan pelayanan penerimaan Peserta Didik Baru pada SD AlFath Cirendeu Tangerang Selatan dilihat dari enam standar pelayanan prima: Prosedur pelayanan yang dinilai sederhana dan mudah dipahami oleh pendaftar; Waktu penyelesaian bergantung pada kecepatan dan ketepatan pendaftar dalam melakukan pembayaran; Semua biaya pelayanan terperinci dengan jelas dan dibayarkan sesuai dengan perincian; Sarana dan prasarana sudah tersedia dengan lengkap serta menunjang kegiatan sehingga menimbulkan rasa aman dan nyaman; Kompetensi petugas pemberi pelayanan dalam Penerimaan Peserta Didik Baru bersikap ramah, sopan, adil dan sesuai dengan bidang keahliannya masingmasing.
\end{abstract}

\section{Kata Kunci: Pelayanan, Peserta Didik Baru}

ABSTRACT:One of the efforts in improving the quality of education services is by screening students in the New Student Admission Program with semi online system. Semi online system of New Student Admission aims to facilitate registration, information and processing of registration results. This research 
method using descriptive qualitative research with data collection techniques used are observation, interview and documentation techniques. The result of implementation of New Student admission service at SD Al-Fath Cirendeu South Tangerang is seen from six excellent service standards: Procedure of service is simple and easily understood by the registrant; Time of service is depends on the speed and accuracy of the registrant in making payments; All service fee detailed clearly and paid in accordance with the details; Facilities and infrastructure available are complete and support activities so as to create a sense of security and comfort; The competence of the service provider in New Student Admission is friendly, courteous, fair and appropriate to their respective areas of expertise.

\section{Key Word: Service, New Student}

\section{PENDAHULUAN}

\section{Latar Belakang}

Pertumbuhan ilmu pengetahuan dan teknologi di era globalisasi ini tidak dipungkiri telah menimbulkan persaingan antar bangsa di segala bidang termasuk pendidikan. Salah satu upaya yang dilakukan bagi lembaga yang bergerak dibidang jasa seperti sekolah adalah dengan meningkatkan mutu pelayanan, hal ini dikarenakan mutu pelayanan dapat dijadikan salah satu strategi oleh sekolah dalam menciptakan kepuasan konsumen mengingat keberhasilan suatu jasa pelayanan sangat bergantung pada konsumennya. Konsumen yang dimaksud disini seperti peserta didik, para orangtua, serta pihak-pihak yang terlibat sebagai pengguna jasa tersebut.

Penerimaan peserta didik baru atau yang disingkat PPDB merupakan kegiatan rutin diselenggarakan setiap tahun oleh sekolah. Kegiatan ini mencakup proses pendaftaran hingga penyeleksian disertai syarat-syarat yang berlaku di sekolah. Namun dalam pelaksanaan PPDB di sekolah swasta pada umumnya tidak dilakukan dengan serius atau ketat serta dengan pelayanan seadanya. Hal ini dikarenakan kurangnya minat dan kepercayaan masyarakat untuk masuk sekolah swasta, selain itu masalah sarana dan prasarana yang belum optimal serta minimnya panitia yang menangani pelaksanaan PPDB juga mengakibatkan 
pelayanan yang diberikan tidak efektif dan kurang maksimal sehingga menyebabkan kurang puasnya calon peserta didik dalam pelaksanaan PPDB. SD Al-Fath Cirendeu merupakan sekolah swasta dwi bahasa bernuansa islami di Tangerang Selatan yang juga melaksanakan Penerimaan Peserta Didik Baru (PPDB) setiap tahunnya. Sekolah ini menggunakan media internet dalam Pelaksanaan Penerimaan Peserta Didik Baru (PPDB) dengan tujuan untuk mempermudah akses informasi bagi calon pendaftar serta sebagai bentuk pelayanan PPDB dengan konsep semi online.

\section{Rumusan Masalah}

Berdasarkan latar belakang di atas, penulis dapat memaparkan perumusan masalah sebagai berikut:

1. Apa saja ketentuan dalam pelaksanaan pelayanan penerimaan peserta didik baru pada SD Al-Fath Cirendeu Tangerang Selatan?

2. Bagaimana pelaksanaan pelayanan penerimaan peserta didik baru pada SD AlFath Cirendeu Tangerang Selatan?

3. Apa saja kendala dan solusi dalam pelaksanaan pelayanan penerimaan peserta didik baru pada SD Al-Fath Cirendeu Tangerang Selatan?

\section{Metode Pengumpulan Data}

Penulis menggunakan beberapa metode penelitian, antara lain:

\section{Metode Observasi}

Penulis melakukan riset di SD Al-Fath Cirendeu Tangerang Selatan untuk mengumpulkan data-data dan informasi dengan mengamati secara langsung dan melihat objek penelitian.

2. Metode Wawancara

Penulis melakukan tanya-jawab langsung kepada pihak-pihak yang terkait sehubungan dengan judul yang penulis ambil untuk mengumpulkan pengetahuan dan informasi dalam penyusunannya.

3. Metode Dokumentasi

Penulis melengkapi data dan informasi dengan membaca dan mempelajari buku-buku, jurnal-jurnal, dokumen riset yang berhubungan dengan pembahasan sesuai dengan judul Tugas Akhir ini sebagai bahan referensi. 


\section{LANDASAN TEORI}

\section{Pengertian Pelayanan}

Menurut Kasmir dalam Rahman (2017) mendefinisikan bahwa "Pelayanan adalah tindakan atau perbuatan seseorang atau organisasi untuk memberikan kepuasan kepada pelanggan atau nasabah".

Menurut Ginting dalam Supeno (2018) yang mengatakan bahwa "Pelayanan prima adalah suatu bentuk pelayanan yang diberikan dengan tatanan yang dibuat sedemikian rupa, sehingga mampu meminimalkan kesalahan serta berorientasi kepada kebutuhan pelanggan".

\section{Tujuan Pelayanan Prima}

Menurut Rahmayanty (2013:8) Tujuan dari service excellence atau pelayanan prima yaitu:

1. Tujuan pelayanan prima mencegah pembelotan dan membangun kesetiaan pelanggan atau customer loyality. Pembelotan pelanggan atau berpalingnya pelanggan disebabkan karena kesalahan pemberian pelayanan maupun sistem yang digunakan oleh perusahaan dalam melayani pelanggan.

2. Tujuan pelayanan prima dapat memberikan rasa puas dan kepercayaan pada konsumennya. Dalam pelaksanaannya pelayanan prima merupakan pelayanan yang sangat baik dan melampaui harapan pelanggan dan pelayanan yang memiliki ciri khas kualitas (quality nice). Kualitas memberikan suatu dorongan kepada pelanggan untuk menjalin hubungan yang kuat dengan pelanggan.

3. Tujuan pelayanan prima tetap menjaga dan merawat (maintenance) agar pelanggan merasa diperhatikan dan dipentingkan segala kebutuhannya atau keinginannya. Pelayanan dengan standar kualitas yang tinggi dan selalu mengikuti perkembangan kebutuhan pelanggan setiap saat, secara konsisten dan akurat.

4. Tujuan pelayanan prima merupakan upaya mempertahankan pelanggan agar tetap loyal untuk menggunakan produk barang atau jasa yang ditawarkan tersebut. 
Manfaat pelayanan prima disampaikan oleh Daryanto dan Setyabudi (2014:51) adalah sebagai berikut:

1. Dapat menciptakan komunikasi yang positif dan harmonis antara perusahaan bisnis dengan kolega dan pelanggan.

2. Dapat mendorong bangkitnya rasa simpatik dan loyalitas dari para kolega dan pelanggan.

3. Dapat membentuk opini publik yang positif, sehingga menguntungkan bagi kemajuan perusahaan.

4. Dapat menimbulkan profitabilitas perusahaan, sehingga mendorong dihasilkan produk baru yang berkualitas.

5. Pelayanan tidak dapat dipisahkan dengan kepuasan pelanggan. Sebab tujuan penerapan pelayanan prima untuk memenuhi kepuasan pelanggan.

\section{Prinsip Pelayanan Prima}

Kepuasan pelanggan akan tercapai jika mampu melaksanakan pelayanan prima dengan baik. Prinsip yang harus diperhatikan dalam pelaksanaan pelayanan prima menurut Daryanto dan Setyabudi (2014:112) yaitu:

1. Mengutamakan pelanggan

Mengutamakan pelanggan disini dalam arti penyedia layanan harus memberikan pelayanan sebaik-baiknya sesuai dengan harapan pelanggan. Selama kegiatan pelayanan berlangsung penyedia layanan harus fokus untuk memberikan pelayanan kepada pelanggan.

\section{Sistem yang efektif}

Artinya dalam proses pelayanan, sistem pelayanan yang diberikan mudah dan tidak membuat pelanggan menjadi kebingungan. Dengan adanya sistem yang efektif, pelanggan akan merasa puas dengan pelayanan yang diberikan.

3. Melayani dengan hati

Artinya selama proses pelayanan berlangsung seorang penyedia layanan harus memberikan pelayanan tulus dan ikhlas serta dengan hati yang bersih. Pelayanan yang menggunakan hati adalah pelayanan dengan menggunakan sikap yang baik, lembut, penuh sopan santun, dan membuat pelanggan merasa tersanjung dengan pelayanannya. Pelayanan yang dilaksanakan dengan hati 
akan tercipta pelayanan yang prima yang membuat pelanggan merasa senang dan merasa percaya dengan pelayanan yang diberikan.

4. Memberdayakan pelanggan

Pelaksanaan pelayanan yang prima, penyedia layanan tidak bertujuan untuk mencari keuntungan dan membuat pelanggan merasa terbebani dengan pelayanan yang diberikan.

\section{Konsep Pelayanan Prima}

Menurut Rangkuti (2016:50-51) konsep pelayanan prima adalah A6. Dengan menggunakan konsep pelayanan prima diyakini perusahaan mampu memenuhi harapan para pelanggan. A6 dalam pelayanan prima adalah sebagai berikut:

1. Ability (Kemampuan)

Pengetahuan dan keterampilan tertentu yang mutlak diperuntukan untuk menunjang program layanan prima.

\section{Attitude (Sikap)}

Perilaku atau perangai yang harus di tonjolkan ketika menghadapi pelanggan.

Sikap mencerminkan perilaku atau gerak-gerik yang terlihat dari diri seseorang ketika dia menghadapi situasi tertentu atau ketika berhadapan dengan orang lain.

3. Appearance (Penampilan)

Penampilan seseorang, baik yang bersifat fisik saja maupun fisik dan nonfisik yang mampu merefleksikan diri dan kredibilitas orang tertentu kepada pihak lain.

4. Attention (Perhatian)

Kepedulian penuh terhadap pelanggan, baik yang berkaitan dengan perhatian atau kebutuhan dan keinginan pelanggan maupun pemahaman atas saran atau kritiknya.

\section{Action (Tindakan)}

Kegiatan nyata yang harus dilakukan dalam memberikan layanan kepada pelanggan. Apabila dikaitkan denan pelaksanaan pelayanan, yaitu upaya atau perbuatan nyata yang ditunjukan untuk memberikan pelayanan yang wajar atau pelayanan yang baik. 


\section{Accountability (Tanggung Jawab)}

Suatu sikap keberpihakan kepada pelanggan sebagai wujud kepedulian untuk menghindarkan atau meminimalkan kerugian atau ketidakpuasan pelanggan.

\section{Pengertian Peserta Didik}

Menurut Undang-Undang Republik Indonesia (Nomor 20 Tahun 2003) "Peserta Didik adalah anggota masyarakat yang berusaha mengembangkan potensi diri melalui proses pembelajaran yang tersedia pada jalur, jenjang, dan jenis pendidikan tertentu".

Menurut Prihatin (2014:4) mengemukakan bahwa "Peserta didik/siswa adalah orang/individu yang mendapatkan pelayanan pendidikan sesuai dengan bakat, minat, dan kemampuannya agar tumbuh dan berkembang dengan baik serta mempunyai kepuasan dalam menerima pelajaran yang diberikan oleh gurunya".

Menurut Ramadhani dalam Farlina dan Hudin (2017) berpendapat bahwa "Penerimaan siswa baru merupakan salah satu proses yang ada di instansi pendidikan seperti sekolah yang berguna untuk menyaring calon siswa yang terpilih sesuai kriteria yang ditentukan oleh sekolah tersebut untuk menjadi siswa didiknya".

\section{Kriteria Penerimaan Peserta Didik Baru}

Menurut Badrudin (2014:38-39) terdapat tiga macam kriteria penerimaan peseta didik yaitu sebagai berikut:

1. Kriteria acuan patokan (standard criterion referenced), yaitu suatu penerimaan peserta didik yang didasarkan atas patokan - patokan yang telah ditentukan sebelumnya.

2. Kriteria acuan norma (norm criterion referenced), yaitu status penerimaan calon peserta didik yang didasarkan atas keseluruhan prestasi peserta didik yang mengikuti seleksi.

3. Kriteria yang didasarkan pada daya tampung sekolah. Sekolah me-ranking prestasi peserta didik mulai yang paling tinggi sampai prestasi yang paling rendah sampai daya tampung tersebut dipenuhi.

\section{Sistem Penerimaan Peserta Didik Baru}


Menurut Prihatin (2014:17) ada dua sistem dalam penerimaan peserta didik baru yaitu:

\section{Sistem promosi}

Sistem promosi adalah penerimaan peserta didik yang sebelumnya tanpa menggunakan seleksi. Peserta didik yang mendaftar di suatu sekolah, diterima tanpa ada penyeleksian terlebih dahulu sehingga yang mendaftar menjadi peserta didik tidak ada yang ditolak. Sistem promosi demikian secara umum berlaku pada sekolah - sekolah yang pendaftarannya kurang dari daya tampung yang ditentukan.

2. Sistem seleksi

Sistem seleksi ini dapat digolongkan menjadi tiga macam yaitu:
a. Seleksi berdasarkan daftar nilai
b. Seleksi berdasarkan penelusuran minat dan kemampuan
c. Seleksi berdasarkan hasil tes masuk.

Saat ini dengan adanya kemajuan teknologi, sekolah sudah mulai banyak menggunakan sistem PPDB online. Maka dalam penyelenggaraannya menggunakan basis internet yang formulir pendaftaran dan nomor peserta dapat diperoleh dari akses web atau blog sekolah.

\section{Prosedur Penerimaan Peserta Didik Baru}

Menurut Imron (2016:47) mengemukakan bahwa:

Prosedur penerimaan peserta didik adalah pembentukan panitia penerimaan peserta didik baru, rapat penentuan peserta didik baru, pembuatan dan pengiriman pengumuman peserta didik baru, pendaftaran peserta didik baru, seleksi peserta didik baru, penentuan peserta didik yang diterima dan pendaftaran ulang peserta didik yang diterima.

Selanjutnya menurut Imron (2016:47-49) tahapan-tahapan dalam penerimaan peserta didik baru yaitu:

1. Pembentukan Panitia Penerimaan Peserta Didik Baru

Kegiatan pertama yang harus dilakukan oleh kepala sekolah dalam penerimaan siswa baru adalah pembentukan panitia. Panitia ini dibentuk dengan maksud agar secepat mungkin melaksanakan pekerjaannya. Biasanya panitia ini 
disusun secara musyawarah untuk menghindari keputusan - keputusan yang tidak demokratis. Panitia yang sudah terbentuk umumnya diformalkan dengan menggunakan surat keputusan dari kepala sekolah atau yayasan. Susunan panitia penerimaan peserta didik baru dapat mengambil alternatif sebagai berikut:
a. Ketua umum
b. Ketua Pelaksana
c. Sekretaris
d. Bendahara
e. Anggota seksi

Susunan kepanitian tersebut memiliki tugas dan fungsinya masing - masing sehingga kegiatan penerimaan peserta didik baru lebih terorganisir dan memudahkan saat pelaksanaan kegiatan penerimaan siswa baru. Penyusunan panitia disesuaikan dengan kebutuhan agar struktur yang dibuat tidak terlalu besar.

\section{Rapat Penentuan Peserta Didik Baru}

Rapat ini berfungsi untuk membuat perencanaan penerimaan peserta didik baru. Dalam rapat ini yang dibicarakan adalah keseluruhan ketentuan penerimaan peserta didik baru. Walaupun penerimaan peserta didik baru merupakan kegiatan rutin yang dilakukan setiap tahun, tetapi ketentuan ketentuan yang berkenaan dengan penerimaan harus senantiasa dibicarakan. Dalam rapat ini, keseluruhan anggota panitia dapat berbicara sesuai dengan kapasitas mereka masing - masing. Aktivitas - aktivitas yang akan dilakukan dibicarakan setuntas mungkin sehingga setelah selesai rapat seluruh anggota panitia hanya perlu menindaklanjuti saja.

3. Pembuatan, Pengiriman/Pemasangan Pengumuman Selanjutnya bagian seksi pengumuman membuat pengumuman yang biasanya berisi hal-hal sebagai berikut:

a. Gambaran singkat mengenai sekolah

b. Persyaratan peserta didik 
c. Cara pendaftaran

d. Waktu pendaftaran

e. Tempat pendaftaran

f. Biaya pendaftaran

g. Waktu dan tempat seleksi dilakukan

h. Pengumuman hasil seleksi

Pembuatan pengumuman hendaknya dilakukan jauh-jauh hari agar pengumuman yang dibuat dapat semenarik mungkin sehingga banyak calon peserta didik baru yang tertarik untuk mendaftar. Pengumuman dapat dilakukan melalui media seperti brosur, spanduk, radio dan website. Selain itu penempatan pengumuman hendaknya yang strategis agar dapat dibaca para calon peserta didik, pengumuman juga dapat dilakukan dengan cara mendatangi sekolah-sekolah secara langsung dan membagikan brosur.

4. Pendaftaran Calon Peserta Didik Baru

Panitia bersiap untuk kedatangan peserta didik yang hendak mendaftar. Yang harus disediakan pada saat pendaftaran peserta didik baru adalah tempat pendaftaran, loket informasi dan formulir pendaftaran. Usahakan untuk menyediakan formulir pendaftaran lebih agar tidak mengganggu selama kegiatan pendaftaran berlangsung. Kemudian tenaga untuk loket pendaftaran pun harus banyak karena terkadang terjadi hal-hal seperti menumpuknya pendaftar, maka diusahakan untuk mengatur antrian agar teratur dan orang tua calon peserta didik tidak kecewa dengan pelayanan penerimaan peserta didik baru yang ada.

\section{Seleksi Peserta Didik Baru}

Kegiatan seleksi penerimaan peserta didik baru ini dapat dilakukan dengan tiga cara yaitu Ujian Nasional, Penelusuran Minat Dan Keterampilan (PMDK) dan tes masuk. Jika yang digunakan sebagai alat seleksi adalah tes masuk maka beberapa hal yang perlu diperhatikan adalah mengatur pengawas tes dan peserta tes. Pengawas perlu diatur agar mereka mengerjakan tugasnya sesuai dengan yang ditentukan, karena pengawas merupakan orang yang bertugas langsung selama kegiatan tes. Untuk itu perlu ditetapkan tata tertib pengawas 
dalam pelaksanaan tes. Peserta tes juga perlu diatur agar mereka dapat mengikuti seleksi sesuai dengan yang ditentukan, hal ini juga untuk memberikan arahan-arahan kepada peserta tes agar mereka tidak merasa bingung selama kegiatan tes berlangsung.

6. Penentuan Peserta Didik Yang Diterima

Cara menentukan peserta didik yang diterima berbeda-beda tergantung sistem penerimaannya jika menggunakan sistem Ujian Nasional maka nilai Ujian Nasional peserta diranking berdasarkan ranking Ujian Nasional yang dibuat sekolah. Jika sekolah menggunakan sistem penerimaan peserta didik baru dengan PMDK maka sekolah mengamati nilai peserta didik melalui buku rapor dan memberikan kriteria atau patokan siapa yang diterima. Sedangkan sekolah yang menggunakan sistem tes maka ketentuannya berdasarkan hasil tes yang dilakukan calon peserta didik.

7. Pendaftaran Ulang Peserta Didik Baru Yang Diterima

Calon peserta yang dinyatakan lulus diharuskan mendaftar ulang dengan memenuhi persyaratan dan perlengkapan yang diminta sekolah. Sekolah harus menetapkan batas waktu.

\section{HASIL PENELITIAN}

\section{Ketentuan Pelayanan Penerimaan Peserta Didik Baru Pada SD Al-Fath Cirendeu Tangerang Selatan}

Pelayanan penerimaan peserta didik baru merupakan pelayanan yang diberikan mulai dari pendaftaran calon peserta didik sampai dengan penerimaan peserta didik menjadi siswa baru di sekolah. Adapun ketentuan pelayanan penerimaan peserta didik baru pada SD AL-Fath Cirendeu Tangerang Selatan adalah sebagai berikut:

1. Pendaftaran Calon Peserta Didik Baru

Pendaftaran calon peserta didik baru pada SD Al-Fath Cirendeu Tangerang Selatan dibuka setiap bulan November - Juli dilakukan secara online melalui website sekolah www.alfathschoolindonesia.sch.id dengan biaya pendaftaran yang dibayarkan melalui transfer Bank Danamon ke rekening Yayasan Bina 
Insan Sakina. Adapun kelengkapan syarat dokumen calon peserta didik baru adalah sebagai berikut:

a. Fotokopi Akta sebanyak 3 lembar

b. Fotokopi Kartu Keluarga sebanyak 2 lembar

c. Fotokopi KTP Orang tua (Ibu dan Ayah) masing-masing sebanyak 1 lembar

d. Pas Foto Berwarna ukuran 2x3, 3x4 dan $3 \mathrm{R}$ masing-masing sebanyak 1 lembar

e. Surat Pernyataan dari Orang tua mengenai peraturan dan tata tertib sekolah Syarat tambahan untuk peserta didik pindahan yaitu:

a. Fotokopi rapor dari sekolah asal

b. Surat keterangan pindah dan tata tertib dari sekolah asal

Semua persyaratan di upload ke website sekolah melalui login dengan akun penerimaan peserta didik baru, selain itu calon peserta didik juga menyerahkan hardcopy nya pada saat proses seleksi di sekolah kepada panitia yang bertugas dalam penerimaan peserta didik baru di SD Al-Fath Cirendeu. Berdasarkan penelitian yang dilakukan di SD Al-Fath Cirendeu, prosedur pendaftaran peserta didik baru dapat dibuat alur sebagai berikut:

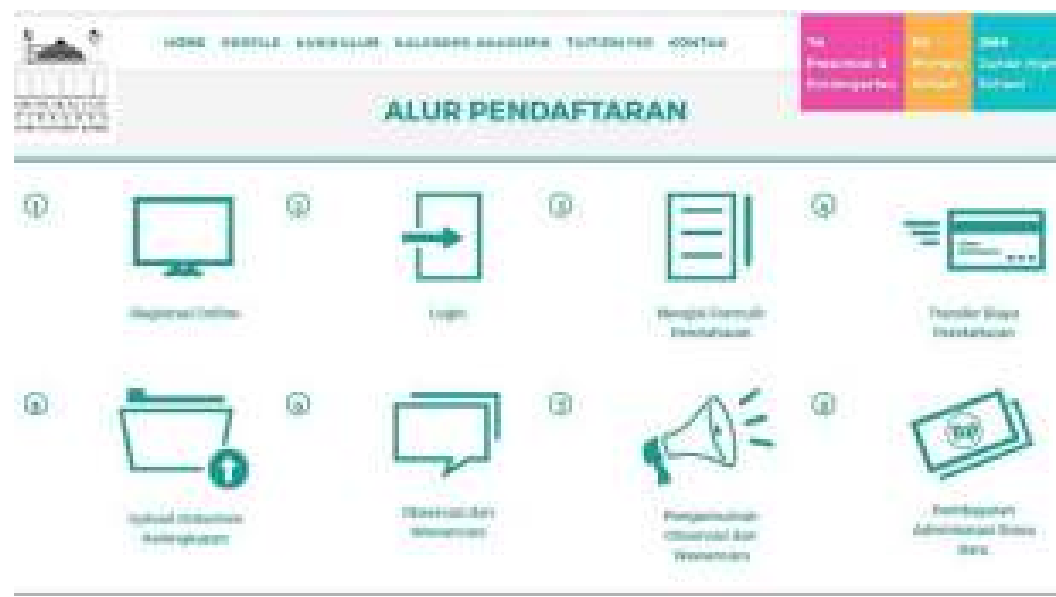

Sumber : Website SD Al-Fath 2017

Gambar 1

Alur Pendaftaran Peserta Didik Baru Pada SD Al-Fath Cirendeu 
Berdasarkan gambar alur pendaftaran di atas dapat dijelaskan sebagai berikut:

a. Pendaftar masuk ke website sekolah dan melakukan registrasi online.

b. Mengisi formulir registrasi pendaftaran yang tertera di dalam website.

c. Pendaftar melakukan transfer pembayaran melalui Bank Danamon ke rekening Yayasan Bina Insan Sakina sesuai dengan invoice yang telah dikirimkan.

d. Upload dokumen syarat kelengkapan penerimaan peserta didik baru sebelum melakukan observasi.

e. Calon peserta didik melaksanakan observasi sesuai dengan jadwal yang telah ditentukan.

f. Calon peserta didik menerima hasil observasi.

g. Calon peserta didik yang dinyatakan lulus observasi dapat langsung melakukan pembayaran administrasi peserta didik baru.

2. Seleksi Penerimaan Peserta Didik Baru

Seleksi penerimaan peserta didik baru bertujuan untuk menyaring calon peserta didik yang sesuai dengan kriteria sekolah. Proses seleksi ini dilakukan setiap hari Sabtu atau Minggu sesuai dengan jadwal observasi yang telah diberikan. Adapun mekanisme seleksi terdapat 4 tahap seleksi yaitu:

a. Seleksi Administrasi, seleksi ini dilakukan untuk mengecek validasi data calon peserta didik. Kelulusan seleksi ini berdasarkan data yang diberikan benar, akurat dan lengkap. Dari seleksi ini sekolah akan memperoleh profil calon peserta didik baru.

b. Tes Wawancara, untuk tahap ini berisi tentang komitmen antara orang tua terhadap anaknya mengenai pelaksanaan pendidikan yang terdapat di sini baik dari peraturan sekolah, metode pengajaran yang diberikan sampai dengan kemampuan pihak orang tua dengan biaya sekolah yang sudah dirinci. Apabila jawaban yang diberikan masih ragu-ragu mengenai komitmen tersebut maka pihak sekolah akan mempertimbangkan bahkan tidak meluluskan. 
c. Tes Akademis, seleksi ini dilakukan untuk mengukur sampai mana kemampuan verbal, kognitif, dan cara calon peserta didik merespon lingkungan luar. Tes ini dilakukan secara klasikal dimana calon peserta didik dikumpulkan di sebuah kelas dengan melakukan kegiatan membaca, menulis dan menghitung. Hal ini bertujuan untuk menggali lebih dalam respon calon peserta didik terhadap banyak hal, sehingga guru penguji dapat mengetahui metode belajar yang pas untuk masing-masing anak.

d. Tes Kesiapan Masuk Sekolah, seleksi ini dilakukan untuk mengetahui masa peka atau kematangan anak untuk belajar secara akademik. Metode tes yang digunakan berupa tes formal dan non formal, dimana pada tes formal ini calon peserta didik akan diminta untuk mengisi lembar pertanyaan yang diberikan oleh guru penguji sedangkan untuk tes non formal yang diberikan yaitu menyanyi dan menggambar.

3. Pengumuman hasil seleksi

Pengumuman hasil seleksi merupakan keputusan sekolah terhadap calon peserta didik yang diterima dan calon peserta didik yang tidak diterima dalam penerimaan peserta didik baru berdasarkan kegiatan penyeleksian yang telah berlangsung. Berdasarkan hasil wawancara dengan koordinator administrasi kesiswaan yang bertugas dalam penerimaan peserta didik baru, pengumuman hasil seleksi ini dikirimkan 1 (Satu) minggu setelah tes berlangsung. Panitia mengumumkan peserta didik yang lulus tes atau di terima melalui email yang digunakan pada saat mendaftar di website sekolah. Calon peserta didik yang sudah dinyatakan lulus dalam penyeleksian akan diberikan jadwal pengukuran seragam dan buku wajib siswa.

\section{Pelaksanaan Pelayanan Penerimaan Peserta Didik Baru Pada SD Al-Fath}

\section{Cirendeu Tangerang Selatan}

Pelaksanaan pelayanan penerimaan peserta didik baru dalam penelitian yang telah dilaksanakan pada SD Al-Fath Cirendeu Tangerang Selatan dapat ditinjau dari enam standar pelayanan prima sebagai berikut:

1. Prosedur Pelayanan 
Prosedur atau tata cara pelayanan yang diselenggarakan harus mudah dipahami, bersifat sederhana, tidak berbelit-belit dan dilaksanakan oleh calon peserta didik yang akan mendaftar di SD Al-Fath Cirendeu Tangerang Selatan. Berdasarkan hasil wawancara dengan orang tua calon peserta didik, prosedur pelayanan penerimaan peserta didik baru yang diterapkan pada SD Al-Fath Cirendeu Tangerang Selatan sudah memenuhi kriteria mudah dipahami karena prosesnya yang sederhana dan tidak berbelit-belit dimana proses pendaftaran dilakukan secara online, calon peserta didik baru hanya perlu membuat akun untuk dapat mengisi formulir register pendaftaran melalui website sekolah. Begitu pula dengan prosedur penyeleksian dan penerimaan seragam peserta didik baru, semua informasi bisa didapatkan melalui email sehingga pendaftar dapat memantau perkembangannya melalui internet dan tidak perlu datang ke sekolah. Hal ini tentu memudahkan para pendaftar karena prosesnya dapat dilakukan dimana dan kapan saja.

2. Waktu penyelesaian

Waktu penyelesaian merupakan waktu yang ditetapkan dalam penerimaan peserta didik baru sejak pendaftaran calon peserta didik baru dilakukan sampai dengan penerimaan. Berdasarkan hasil wawancara yang dilakukan dengan Koordinator Administrasi Kesiswaan SD Al-Fath Cirendeu Tangerang Selatan, waktu penyelesaian penerimaan peserta didik baru meliputi:

a. Pendaftaran Penerimaan Calon Peserta Didik Baru, calon peserta didik baru yang mendaftar di SD Al-Fath Cirendeu Tangerang Selatan akan menerima verifikasi dan invoice biaya pendaftaran melalui email sebagai tanda bahwa data formulir registrasi telah diterima sekolah. Proses verifikasi itu sendiri dilakukan setiap hari kerja yaitu setiap hari Senin Jumat.

b. Seleksi Penerimaan Peserta Didik Baru, calon peserta didik baru akan menerima jadwal seleksi selama 2-3 hari setelah peserta didik baru melakukan pembayaran pendaftaran yang telah dikirimkan saat verifikasi. 
c. Pengumuman Hasil Seleksi Penerimaan Peserta Didik Baru, calon peserta didik baru akan menerima hasil seleksi 1 (satu) minggu setelah seleksi dilakukan melalui email. Pengumuman ini berisikan informasi mengenai status calon peserta didik baru apakah diterima atau tidak, persyaratan administrasi peserta didik baru, serta tanggal pengukuran dan penerimaan seragam peserta didik baru.

3. Biaya pelayanan

Rincian biaya pelayanan penerimaan peserta didik baru biasanya didapatkan melalui lembaran brosur maupun website sekolah.

4. Produk Pelayanan

Dalam penyelenggaraan penerimaan peserta didik baru pada SD Al-Fath Cirendeu Tangerang Selatan, sekolah juga memperhatikan produk pelayanan yang ada diantaranya meliputi: pelayanan pendaftaran calon peserta didik baru, pelayanan seleksi calon peserta didik baru serta pelayanan penerimaan seragam dan buku wajib peserta didik baru. Produk pelayanan yang dihasilkan harus sesuai dengan harapan dan kebutuhan calon pesera didik agar peserta didik maupun orang tua merasa puas dengan pelayanan yang diberikan. Berdasarkan hasil wawancara dengan Koordinator Administrasi Kesiswaan, produk pelayanan yang diberikan sudah sesuai dengan kebutuhan calon peserta didik. Hal ini dapat dilihat dari sistem penerimaan peserta didik baru yang ada dimana prosesnya sederhana dan tidak berbelit-belit, selain itu penyediaan seragam dan buku wajib peserta didik baru juga dapat menunjang kegiatan belajar-mengajar di sekolah.

5. Sarana dan Prasarana

Sarana dan prasarana yang lengkap akan mendukung pelaksanaan pelayanan yang prima. Sarana dan prasarana yang dipakai dalam penerimaan peserta didik baru pada SD Al-Fath Cirendeu Tangerang Selatan yaitu ruangan kelas yang digunakan untuk kegiatan observasi, adapun ruangan yang dipakai dalam kegiatan ini berjumlah 4 kelas (2 untuk ruang tunggu, 1 ruang observasi dan 1 ruang wawancara orang tua). Selain itu didalam kelas 
terdapat meja, kursi, AC (Air Conditioner), papan tulis, komputer, rak buku, lemari dan juga ATK. Berdasarkan pengamatan, sarana dan prasarana yang tersedia sudah lengkap namun dari hasil wawancara dengan Koordinator Kesiswaan masih terdapat kendala dalam sarana dan prasarana yaitu berupa gangguan sistem pada program yang dipakai dalam penerimaan peserta didik baru yang dapat menghambat proses penerimaan peserta didik baru pada SD Al-Fath Cirendeu Tangerang Selatan.

6. Kompetensi Petugas Pemberi Pelayanan

Kompetensi petugas pemberi layanan berkaitan dengan keramahan, kesopanan, pengetahuan dan keterampilan dari pemberi layanan. Petugas yang memberikan pelayanan dengan sikap ramah akan memberikan penilaian yang baik terhadap pelayanan yang diberikan. Petugas penerimaan peserta didik baru pada SD Al-Fath Cirendeu Tangerang Selatan dalam memberikan pelayanannya didasarkan pada sikap 5S (Salam, Senyum, Sapa, Sopan \& Santun). Berdasarkan hasil wawancara dengan orang tua calon peserta didik baru, petugas pemberi layanan pada SD Al-Fath Cirendeu Tangerang Selatan sudah memenuhi kriteria ramah, sopan, adil dan melayani sesuai dengan bidang keahliannya masing-masing. Hal ini dapat dilihat dari bagaimana sikap petugas pemberi layanan dalam melayani dan menanggapi keluhan pendaftar.

Adapun dokumen yang digunakan dalam pelaksanaan pelayanan penerimaan peserta didik baru pada SD Al-Fath Cirendeu Tangerang Selatan adalah sebagai berikut:

1. Formulir Pendaftaran

2. Fotokopi Akta

3. Fotokopi Kartu Keluarga

4. Fotokopi KTP Orang Tua

5. Foto Berwarna ukuran $2 \times 3,3 \times 4$ dan $3 R$

6. Surat Pernyataan dari Orang tua mengenai peraturan dan tata tertib sekolah

Proses pelayanan penerimaan peserta didik baru pada SD Al-Fath Cirendeu Tangerang Selatan dapat dibuatkan alur sebagai berikut: 


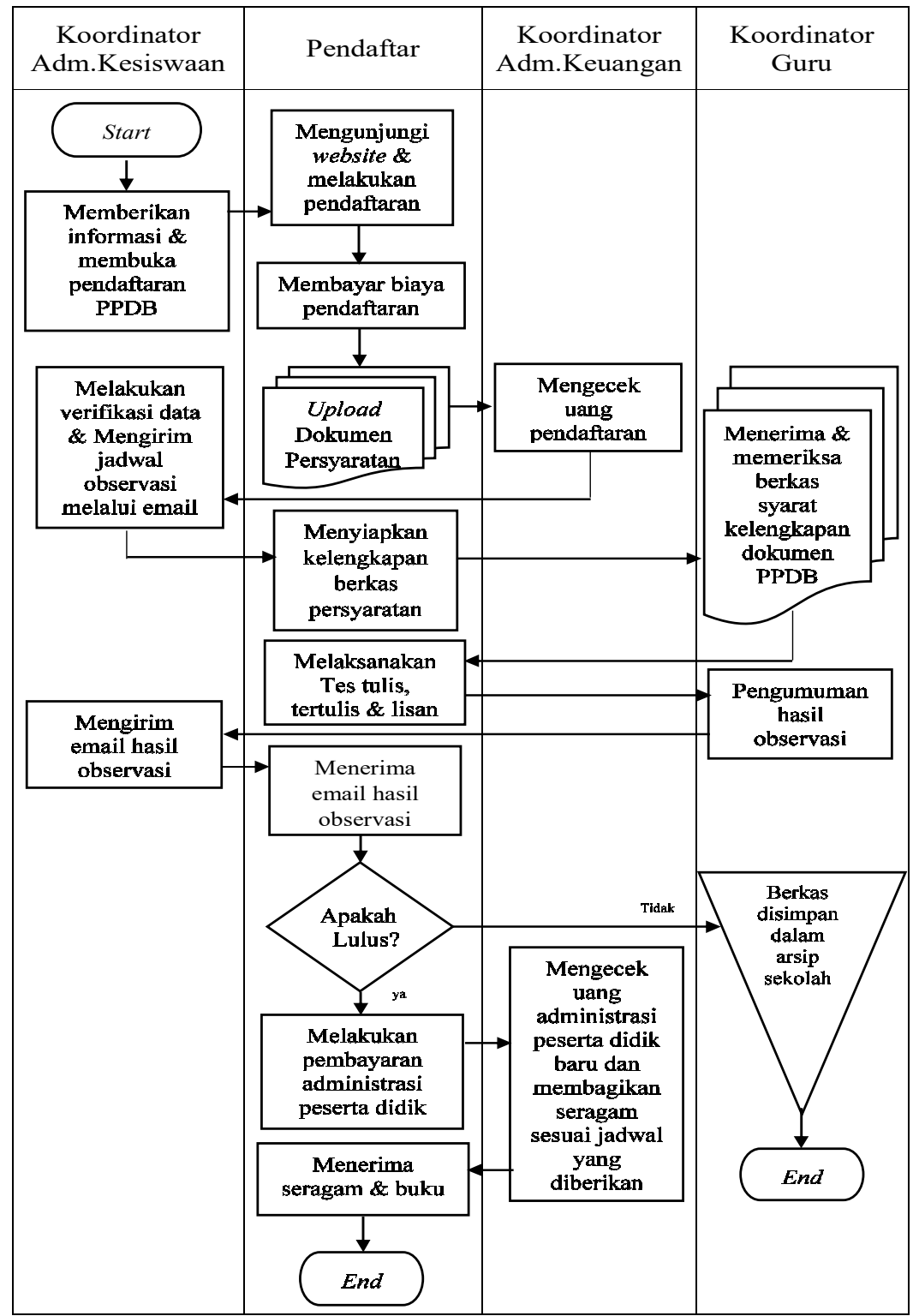

Sumber : SD Al-Fath Cirendeu 2017

Gambar 2

Alur Pelaksanaan Pelayanan Penerimaan Peserta Didik Baru

SD Al-Fath Cirendeu Tangerang Selatan

Berdasarkan alur pelaksanaan pelayanan penerimaan peserta didik baru pada SD Al-Fath Cirendeu Tangerang Selatan seperti yang terlihat pada gambar flowchart di atas dapat dijelaskan sebagai berikut:

1. Koordinator Administrasi Kesiswaan memberikan informasi dan membuka pendaftaran penerimaan peserta didik baru melalui brosur dan website sekolah. 
2. Calon peserta didik baru melakukan pendaftaran online dengan mengunjungi website sekolah www.alfathschoolindonesia.sch.id, setelah itu klik Daftar Sekarang dan membuat account penerimaan peserta didik baru seperti yang tertera pada gambar di bawah ini.

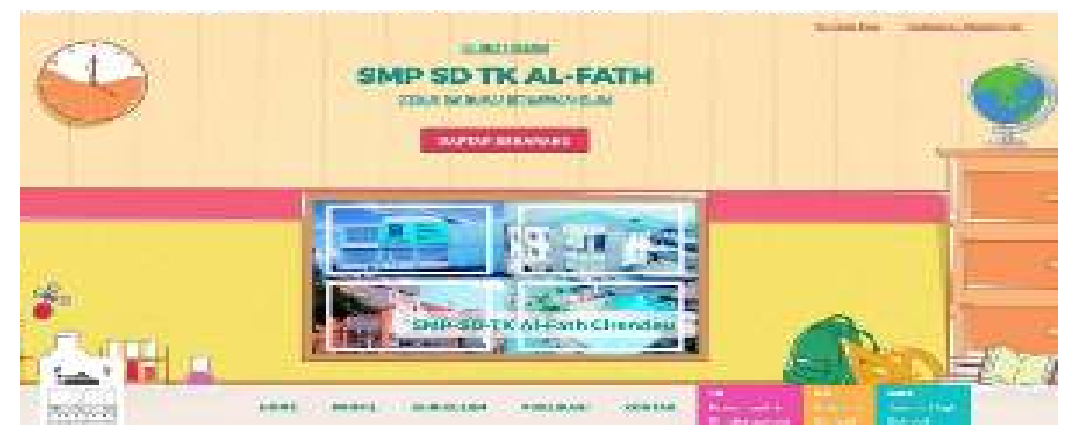

Sumber : Website SD Al-Fath 2018

Gambar 3

Tampilan Awal Website SD Al-Fath

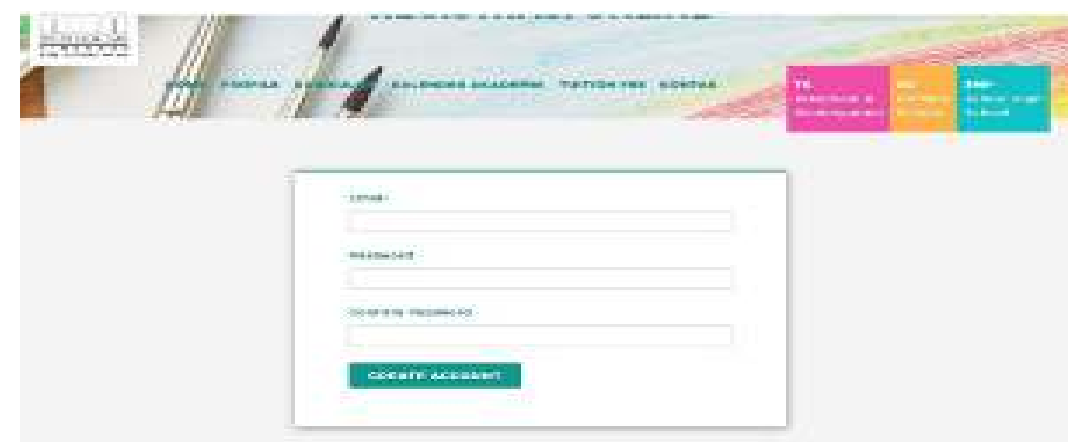

Sumber : Website SD Al-Fath 2018

Gambar 4

Tampilan Creat Account Penerimaan Peserta Didik Baru SD Al-Fath

Jika account Penerimaan Peserta Didik Baru sudah dibuat, maka akan muncul tampilan seperti gambar di bawah ini dan klik Isi Form Registrasi untuk melengkapi data formulir registrasi pendaftaran penerimaan peserta didik baru. 


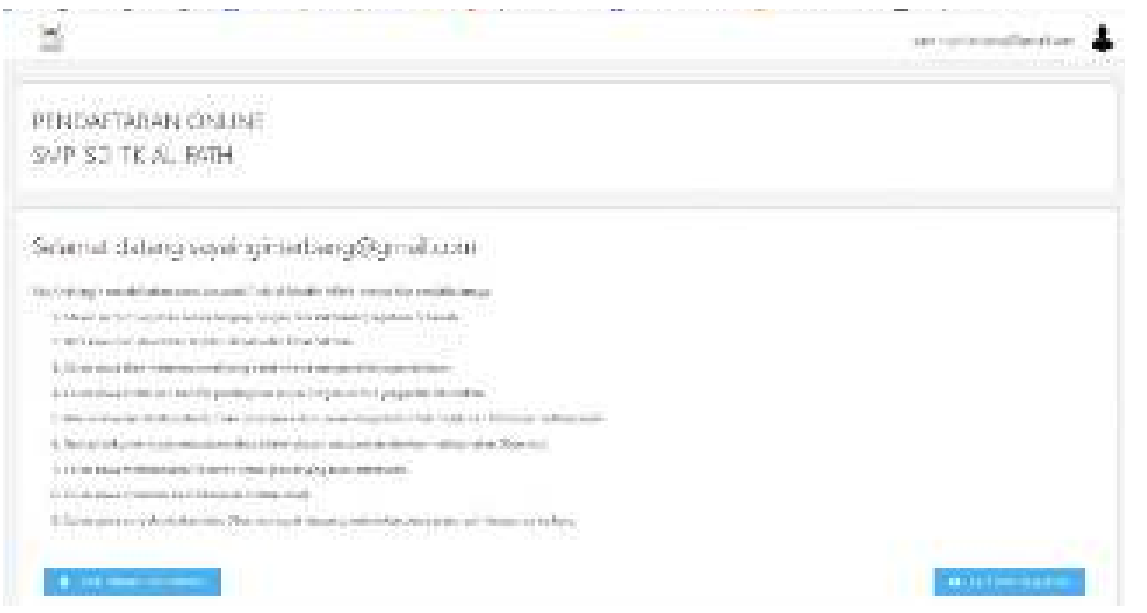

Sumber : Koordinator Administrasi Kesiswaan SD Al-Fath Cirendeu 2018

Gambar 5

\section{Tampilan Halaman Awal Saat Login}

3. Setelah formulir registrasi selesai diisi, calon peserta didik menunggu verifikasi data dan melakukan pembayaran pendaftaran dengan mengeklik Lihat Rincian, maka akan muncul pilihan metode pembayarannya seperti

$\mathrm{g}$

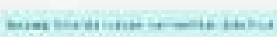

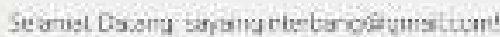

Sumber : Koordinator Administrasi Kesiswaan SD Al-Fath Cirendeu 2018

Gambar 6 


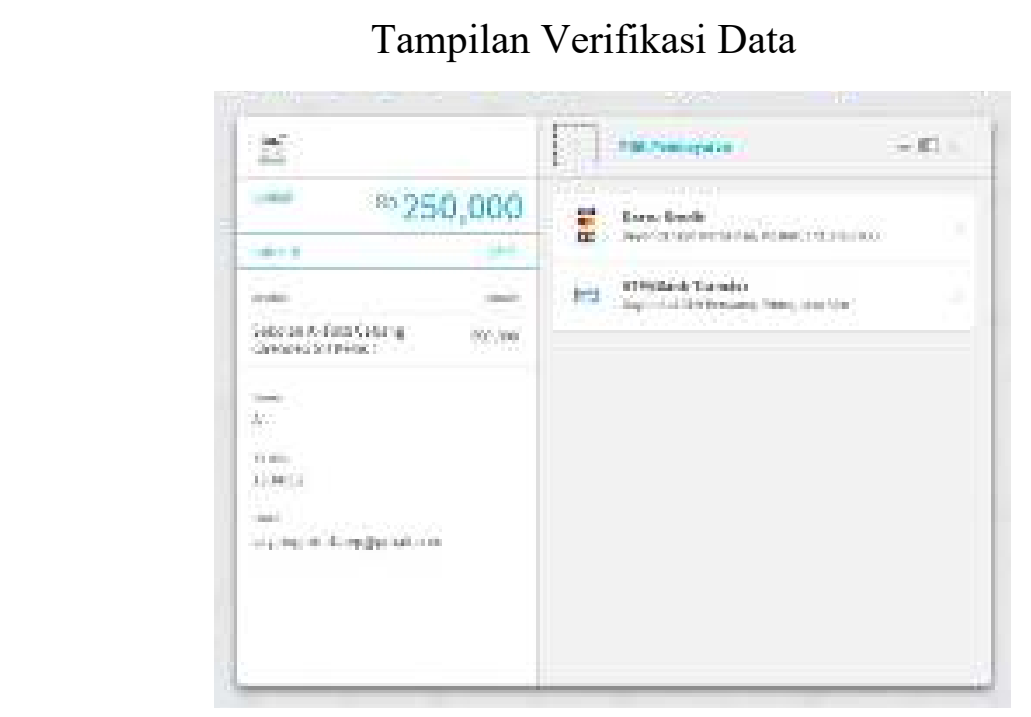

Sumber : Koordinator Administrasi Kesiswaan SD Al-Fath Cirendeu 2018 Gambar 7

Tampilan Pilihan Metode Pembayaran Pendaftaran

4. Setelah itu calon peserta didik dapat melengkapi dokumen dengan cara klik Upload Dokumen untuk mendapatkan verifikasi dan jadwal observasi serta sebagai syarat menjadi peserta observasi.

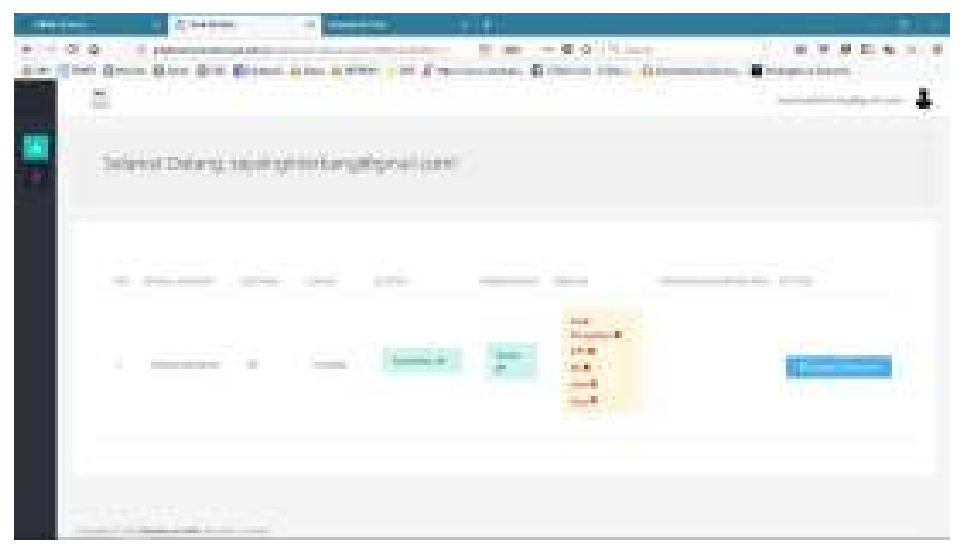

Sumber : Koordinator Administrasi Kesiswaan SD Al-Fath Cirendeu 2018 Gambar 8

Tampilan Upload Dokumen

5. Selanjutnya Koordinator Administrasi Keuangan akan mengecek uang pendaftaran yang masuk. 
6. Setelah proses pembayaran biaya pendaftaran berhasil, maka Koordinator Administrasi Kesiswaan melakukan verifikasi data dan mengirimkan email jadwal observasi seperti gambar di bawah ini.

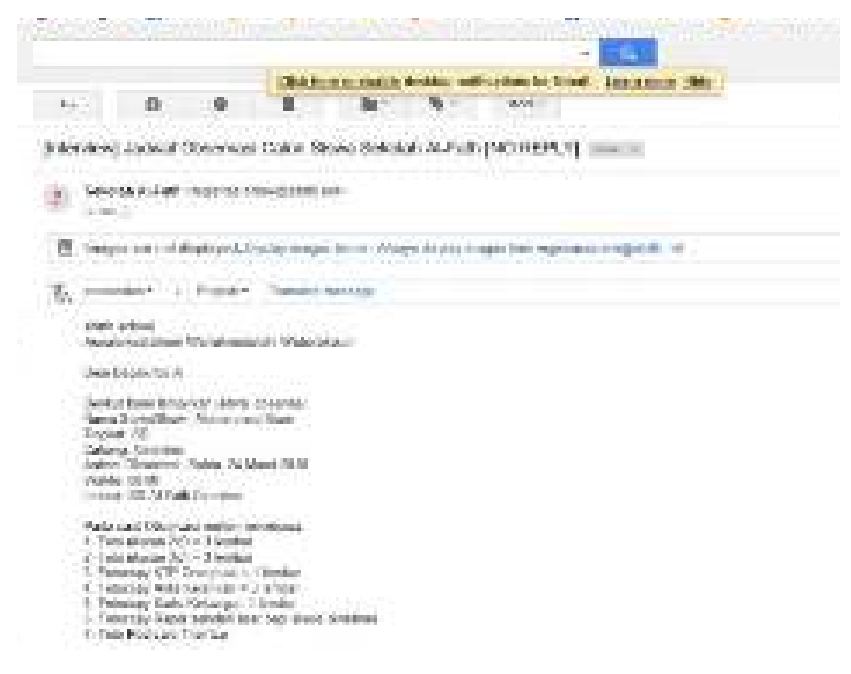

Sumber : Koordinator Administrasi Kesiswaan

SD Al-Fath Cirendeu 2018

Gambar 9

Contoh Email Pemberitahuan Jadwal Observasi

7. Calon peserta didik baru yang telah mendapatkan jadwal observasi dapat menyiapkan berkas syarat kelengkapan dokumen penerimaan peserta didik baru untuk diserahkan kepada panitia saat observasi.

8. Selanjutnya Koordinator Guru yang bertugas dalam melaksanakan observasi akan menerima dan memeriksa berkas syarat kelengkapan dokumen calon peserta didik dalam penerimaan peserta didik baru pada SD Al-Fath Cirendeu Tangerang Selatan.

9. Setelah berkas syarat kelengkapan dokumen penerimaan peserta didik baru diterima oleh Koordinator Guru maka calon peserta didik baru kemudian melaksanakan observasi berupa tes tulis, tertulis dan lisan.

10. Koordinator Guru yang bertugas saat observasi akan memberikan hasil observasi yang telah dilakukan calon peserta didik baru kepada Koordinator Administrasi Kesiswaan untuk dikirimkan melalui email. 
11. Selanjutnya Koordinator Administrasi Kesiswaan akan mengirimkan email hasil observasi dan invoice administrasi peserta didik baru kepada calon peserta didik seperti gambar di bawah ini.

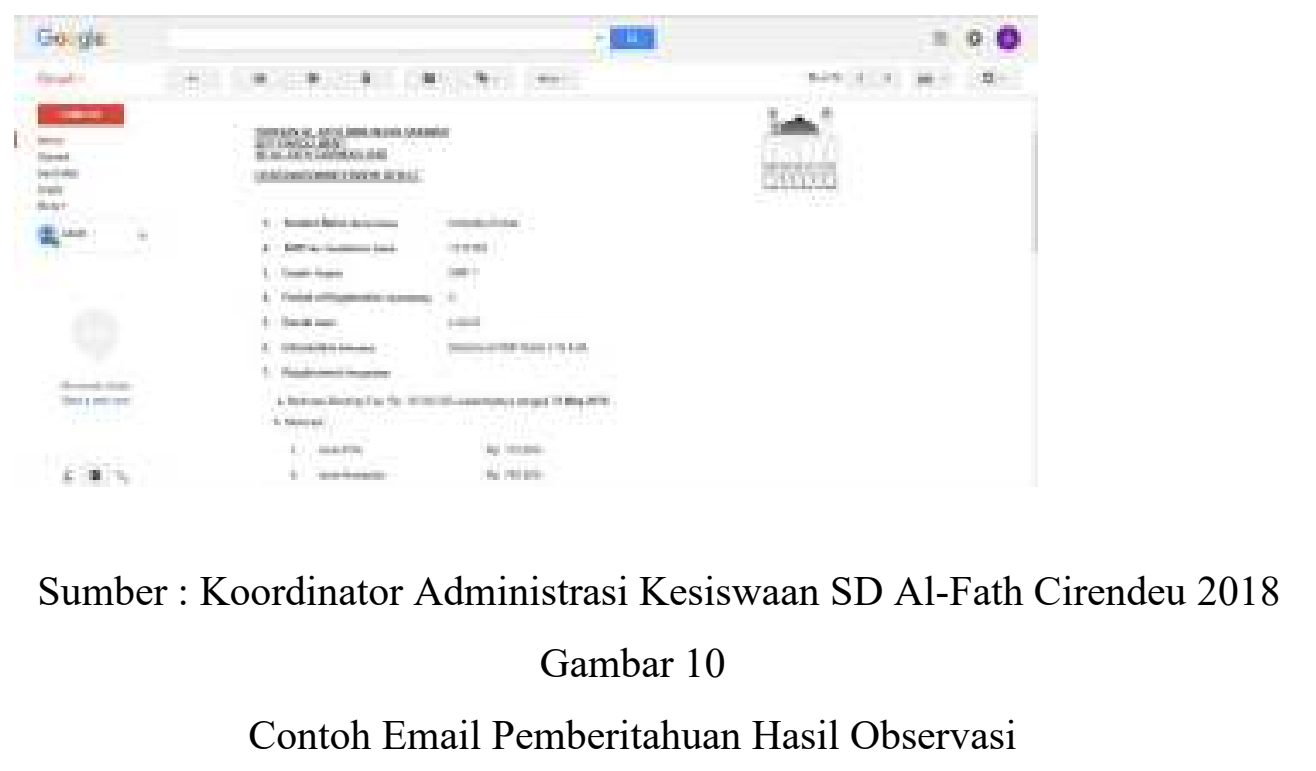

12. Calon peserta didik yang telah melaksanakan observasi akan menerima email hasil observasi.

a. Bagi calon peserta didik yang dinyatakan lulus dapat langsung melakukan pembayaran administrasi peserta didik baru.

b. Bagi calon peserta didik yang dinyatakan tidak lulus, maka berkas syarat kelengkapan dokumen penerimaan peserta didik baru yang telah diserahkan akan disimpan kedalam arsip sekolah.

13. Koordinator Administrasi Keuangan mengecek uang administrasi peserta didik baru yang masuk untuk membuat list pembagian seragam.

14. Peserta didik baru menerima seragam dan buku wajib siswa.

Kendala dan Solusi Pelaksanaan Pelayanan Penerimaan Peserta Didik Baru Pada SD Al-Fath Cirendeu Tangerang Selatan

1. Sistem pada program komputer yang dipakai dalam penerimaan peserta didik baru pada SD Al-Fath Cirendeu Tangerang Selatan kadang bermasalah saat operator hendak memeriksa status pembayaran, status pembayaran yang seharusnya terbayar berubah menjadi pending atau gagal. Hal ini dikarenakan 
pendaftar terlalu lama tidak melakukan pembayaran dan melebihi batas waktu yang ada (24 jam) sehingga mengakibatkan tertundanya proses verifikasi status pembayaran maupun pengiriman jadwal observasi kepada calon peserta didik baru.

Berdasarkan kendala di atas solusinya adalah sekolah biasanya melakukan konfirmasi kepada orang tua calon peserta didik yang status pembayarannya belum berubah/terverifikasi, setelah itu operator akan mengubah secara manual status pembayaran. Pendaftar yang status pembayarannya telah berhasil dirubah akan dihubungi kembali oleh pihak sekolah.

2. Kurangnya ketepatan waktu dari orang tua atau pihak calon peserta didik dalam melakukan pembayaran administrasi peserta didik baru yang menyebabkan status calon peserta didik menjadi menggantung, hal ini dikarenakan adanya orang tua calon peserta didik yang mendaftar di SD AlFath Cirendeu Tangerang Selatan sebagai alternatif ketika tidak diterima di SD Negeri.

Berdasarkan kendala di atas solusinya adalah sekolah biasanya menyediakan batas waktu 2 minggu untuk pelunasan biaya administrasi peserta didik baru, selain itu bagi orang tua calon peserta didik yang ingin melakukan pembayaran dengan cara menyicil akan disarankan untuk membuat surat pernyataan penangguhan.

\section{KESIMPULAN}

1. Ketentuan dalam penerimaan peserta didik baru pada SD Al-Fath Cirendeu Tangerang Selatan dimulai dari tahap pendaftaran yang dilakukan secara online melalui website sekolah sedangkan untuk penyeleksian/observasi dilakukan secara offline di sekolah. Adapun dokumen yang diperlukan yaitu berupa fotokopi akta, fotokopi $\mathrm{KK}$, fotokopi KTP orang tua, pas foto berwarna dan surat pernyataan orang tua mengenai tata tertib sekolah serta tambahan untuk peserta didik pindahan yaitu fotokopi rapor dan surat keterangan pindah dari sekolah asal.

2. Pelaksanaan pelayanan penerimaan peserta didik baru pada SD Al-Fath Cirendeu Tangerang Selatan sudah dilakukan sesuai dengan ketentuan 
dimana ditinjau dari prosedur pelayanan yang dianggap mudah dipahami dan dilaksanakan oleh orang tua maupun pendaftar, biaya pelayanan yang dikeluarkan oleh orang tua calon peserta didik pun sudah sesuai berdasarkan informasi yang tertera di website maupun brosur sekolah, begitu pula dengan sarana dan prasarana yang tersedia sudah lengkap serta kompetensi petugas pemberi layanan sudah melayani dengan ramah dan sopan tanpa membedabedakan golongan, suku dan ras.

3. Kendala yang ada dalam penerimaan peserta didik baru yaitu waktu penyelesaian pelayanan yang bergantung pada kecepatan dan ketepatan orang tua/pendaftar dalam melakukan pembayaran pendaftaran maupun administrasi peserta didik baru sehingga dapat menghambat proses penerimaan peserta didik baru.

Adapun saran yang dapat diberikan penulis dalam pelaksanaan pelayanan penerimaan peserta didik baru pada SD Al-Fath Cirendeu Tangerang Selatan yaitu sebagai berikut:

1. SD Al-Fath Cirendeu Tangerang Selatan sebaiknya melakukan maintenance sistem pada program penerimaan peserta didik baru yang dilakukan secara online guna meminimalisir kendala yang dihadapi oleh petugas yang menangani pendaftaran dalam penerimaan peserta didik baru agar proses pendaftaran tidak tertunda dan dapat berjalan sesuai dengan waktu yang telah ditentukan.

2. SD Al-Fath Cirendeu Tangerang Selatan sebaiknya meningkatkan sosialisasi dalam pemberitahuan informasi mengenai penerimaan peserta didik baru agar orang tua calon peserta didik yang akan mendaftar dapat mengetahui info penerimaan peserta didik baru dengan jelas dan lebih yakin dengan kelebihan yang dimiliki SD Al-Fath Cirendeu di banding dengan sekolah negeri yang ada disekitar. 


\section{DAFTAR PUSTAKA}

Badrudin. 2014. Manajemen Peserta Didik. Jakarta: PT. Indeks.

Daryanto, dan Ismanto Setyabudi. 2014. Konsumen Dan Pelayanan Prima. Yogyakarta: Gava Media.

Farlina, Yusti., dan Hudin Jamal Maulana. 2017. Kajian Kepuasan Pengguna Informasi Penerimaan Peserta Didik Baru ( PPDB ) Online. Indonesian Journal on Computer and Information Technology, 2(2), 48-54. Diambil dari: http://ejournal.bsi.ac.id/ejurnal/index.php/ijcit/article/view/2778/1824. (10 Mei 2018)

Frimayasa, Agtovia. 2017. Konsep Dasar dan Strategi Pelayanan Prima (Service Excellent) Pada Indosat Ooredo. Cakrawala-Jurnal Humaniora, 17(1), 6571. Diambil dari:

http://ejournal.bsi.ac.id/ejurnal/index.php/cakrawala/article/view/1882. (11 Mei 2018)

Frimayasa, Agtovia., dan Kamal Fahmi. 2017. Harapan Masyarakat Terhadap Layanan Publik Pada Kelurahan Makasar, Jakarta Timur. XVII(2), 179-188. Diambil dari: http://ejournal.bsi.ac.id/ejurnal/index.php/cakrawala/article/view/2428. (10 Mei 2018)

Imron, Ali. 2016. Manajemen Peserta Didik Berbasis Sekolah. Jakarta: PT Bumi Aksara.

Prihatin, Eka. 2014. Manajemen Peserta Didik. Bandung: Alfabeta.

Rahman, Aan. 2017. Pengaruh Pelayanan Terhadap Kepuasan Pelanggan (Studi Kasus : Rumah Makan Ayam Bakar Penyet KQ5 Mayestik Jakarta Selatan). XVII(2), 237-242. Diambil dari:http://ejournal.bsi.ac.id/ejurnal/index.php/cakrawala/article/download/2 504/1799. (10 Mei 2018)

Rahmayanty, Nina. 2013. Manajemen Pelayanan Prima. Yogyakarta: Graha Ilmu. Rangkuti, Fredy. 2016. Customer Care Excellence Meningkatkan Kinerja Perusahaan Melalui Pelayanan Prima. Jakarta: Gramedia Pustaka Utama. Ratminto, dan Atik Septi Winarsih. 2013. Manajemen Pelayanan. Yogyakarta: 
Pustaka Belajar.

Sediawan, Ricky. 2015. Analisis Dalam Menciptakan Kualitas Pelayanan Untuk Mengarah Pada Kepuasan Konsumen. Jurnal Ilmu Komunikasi (J-IKA), II(1), 1-10. Diambil dari:

http://ejournal.bsi.ac.id/ejournal/index.php/jika/article/view/197/165. (11 Mei 2018)

Supeno, Wangsit. 2018. Analisis Penilaian Kepuasan Pelayanan Hotel Pelanggan Traveloka (Studi Kasus Hotel di Area Malioboro Yogyakarta), XVI(1).

Diambil dari:

http://ejournal.bsi.ac.id/ejurnal/index.php/perspektif/article/view/3050/2060. (11 Mei 2018)

Undang-Undang Republik Indonesia. (2003). Sistem Pendidikan Nasional. Jakarta. 